https://doi.org/10.25312/2391-5137.14/2020_02ww

\author{
Włodzimierz Wysoczański (iD) http://orcid.org/0000-0003-3516-3240 \\ Uniwersytet Wrocławski \\ e-mail: wlodzimierz.wysoczanski@uwr.edu.pl
}

\title{
Złożenia z komponentem biało w językach słowiańskich
}

\section{Streszczenie}

Wśród jednostek z nazwą barwy białej w zasobie językowym wyraźną grupę stanowią złożenia. Rozpatrywany materiał języków słowiańskich poświadcza dużą liczebność kompozycji z odwołaniem do barwy białej o charakterze nieterminologicznym. W ich obrębie można wyróżnić kilka zasadniczych pól tematycznych, z których najbardziej reprezentatywne są odnoszące się do człowieka, przede wszystkim do wyglądu zewnętrznego oraz społecznego wymiaru życia, a także mieszczące się w polu tematycznym zwierzęta. Bogaty jest też zasób terminologiczny złożeń z komponentem biało, który stanowią głównie terminy biologiczne botaniczne i zoologiczne, anatomiczno-medyczne i techniczne, w mniejszym stopniu należące do innych elementów świata.

Słowa kluczowe: barwa biała, analiza kolorystyczna, złożenia, języki słowiańskie

\section{Barwa biała w strukturach złożeniowych}

Zauważa się, że istnieją wielorakie sposoby wyrażania w języku informacji o kolorze:

Oprócz prymarnego wykładnika przymiotnikowego predykaty koloru mają wykładniki rzeczownikowe, przysłówkowe i czasownikowe. Informacja o kolorze może być przekazywana także przez bardziej złożone struktury wiążące więcej wyrażeń, jak porównania czy frazy opisowe (kolor x jest jak kolor krwi; $x$ jest $w$ kolorze zielonkawego likieru) (Ampel-Rudolf, 1994: 9).

W dociekaniach poświęconych semantyce barw słusznie wysuwane jest stwierdzenie o pierwszoplanowej pozycji barwy białej, por. „biały, czarny i szary w językowej kon- 
ceptualizacji barw zajmują miejsce szczególne" (Tokarski, 1995: 35)1․ Biały jako kolor tworzący skalę podstawową wyrażają wykładniki: biały, biel, białość, bielić się, bieleć, biało, definiowany bywa następująco: $\mathrm{x}$ jest biały $\rightarrow \mathrm{x}$ ma kolor taki $\rightarrow$, biały $\mathrm{x} \rightarrow$ kolor $\mathrm{x}$ jest taki $\rightarrow$, biały $\rightarrow$ kolor taki $\rightarrow$, zwykle z założeniem definicyjnym - biały to 'kolor śniegu', zaś wśród obiektów naturalnych, o których prawdziwie orzekamy ten predykat, wymieniane są: mleko, kreda, skała wapienna, wapno, alabaster, przebiśniegi (zob. Ampel-Rudolf, 1994: 51, 63-64). Jednostki z nazwą barwy białej są w zasobie językowym wyraźnie widoczne, por. np. pol. biały jak gołą, biały węgiel; słowac. biely ako sneh, biele uhlie; białorus. бель вугаль; ros. бельй, как снег, бельий уголь; chorw. bijeli ugljen . Poświadczają to badania utrwalonych połączeń wyrazowych, w szczególności zestawień, a także łączliwości leksykalnej (zob. np. Budniak, 1987: 93-97; Tokarski, 1995: 35-85; Skorupska-Raczyńska, 2003: 337-356; Ignatowicz-Skowrońska, 2010: 69-80; Osuchowska, 2010: 175-184; Wysoczański, 2014: 567-585).

Przedkładana analiza złożeń z segmentem biało- w językach słowiańskich pod kątem analizy kolorystycznej ma na celu odtworzenie językowych sposobów ujmowania określonego wycinka rzeczywistości. Zaprezentowane zostaną złożenia traktowane w szerokim rozumieniu jako nieterminologiczne oraz mieszczące się w sferze słownictwa profesjonalno-naukowego i nazw oficjalnych.

Prasłowiańskie bĕlı bĕla bĕlo to mający barwę przeciwstawną do czarnej, właściwą śniegowi, mleku (albus), także: 'mający barwę zbliżoną do białej’, ‘jasny; czysty’ (zob. Sławski, 1974: 238). Należy zauważyć, że „rozwój znaczeniowy przymiotnika biały idzie w dwóch kierunkach: z jednej strony wykazuje związek ze zjawiskami błyszczenia i świecenia, z drugiej z barwami bezpośrednio sąsiadującymi z bielą na linii barw neutralnych" (Zaręba, 1954: 11). W związku z podejmowanym zagadnieniem istotne jest zauważenie, że nadmienione odniesienia i prawidłowości poświadczają derywaty sufiksalne $(<$ běls 'biały'), wskazując równocześnie na wieloaspektowość znaczeniową oraz na wielorakie odwołania przedmiotowe. W języku prasłowiańskim nadmienione derywaty potwierdzają następujące znaczenia: 'biel, białość', por. bĕloba; 'biel, białość; coś białego, np. biała plama, białko jajka, oka', por. bĕlina; 'biel, białość; to, co białe, np. biała odzież, gleba, biaława warstwa drewna pod korą', por. běliznna; 'albulus', por. bĕlıkъ; 'o barwie zbliżonej do białej', por. psł. bělası : běl’asz : bělası; 'coś białego, białawego', por. bělıka; 'coś białego, białawego, biel, bielidło’, por. běl'b; 'coś białego, białawego, np. ziemia, zwierzę, ryba, roślina', por. běluga; 'człowiek lub zwierzę wyróżniające się bielą', por. bělochı, bĕlocha; 'człowiek lub zwierzę koloru białego, białawego', por. běluchъ; 'wyróżniający się bielą', por. bělbša; 'ktoś lub coś wyróżniające się bielą', por. bělucha, bělašb, bělišb, bělošb, běloša, bělušb, běluša, bělikъ; 'człowiek wyróżniający się bielą; zwierzę białej maści', por. bělbsb; 'środek do bielenia; miejsce, gdzie się coś bieli’, por. bělïdlo (< běliti 'czymś białym powlekać, bielić') (zob. Sławski, 1994: 9-123).

\footnotetext{
1 Por. np. pol. biała kawa, czarna kawa, biały chleb, czarny chleb (razowy, żytni) - czes. bilá káva, černá káva, bílý chléb, černý chléb. Stosowane skróty nazw języków: białorus. - białoruski, bułg. - bułgarski, chorw. chorwacki, stczes. - staroczeski, czes. - czeski, dłuż. - dolnołużycki, głuż. - górnołużycki, mac. - macedoński, stpol. - staropolski, pol. - polski, psł. - prasłowiański, ros. - rosyjski, słowac. - słowacki, słoweń. - słoweński, serb. - serbski, ukr. - ukraiński.
} 
W prezentacji kolorystycznej bieli wyróżniają się złożenia, tj. formacje pochodne zwykle od dwóch wyrazów, oparte na dwóch tematach słowotwórczych - odpowiednio członie A oraz członie B (zob. Grzegorczykowa, 1984: 59), por. np. pol. czarno-biały, np. telewizja czarno-biała, słowac. čierno-biely, np. žeriav čierno-biely [żuraw], čierno-biela televizia [telewizja], czes. černobilý, chorw. crno-bijel 'koji je dijelom crn i dijelom bijel', crno-bijelo 'opisano samo u krajnostima', ros. чёрно-бельий; pol. czerwono-biaty, czes. červenobilý, ros. красно-бельй; pol. srebrzystobiaty, siwobiaty, zielono-biaty 'zielony i biały', zielonobiaty 'biały z zielonym odcieniem', liliowobiały; czes. červenomodrobílý [czerwono-niebiesko-biały]; ros. вишнёво-бельй [wiśniowo-biały]; простынно-бельий [prześcieradłowo-biały], рыље-бельй [rudo-biały]. Wśród złożeń ważne miejsce zajmują jednostki z komponentem biało, por. np. pol. białowtosy (wyraz pochodny od białoi włosy)'; głuż. běłohlinjany (béło- i hlina 'glina', por. pol. białoglinaty 'zielonawy'); ros. белотропье (бельй + o + тропа [ścieżka; szlak] + j(e)), белокрепкий [крепкий mосnу], белотрубый [труба - rura; komin]; chorw. bjelobrad (bijel- i brada [broda]), bjelomusilo (bijel- i [włoskie] muso - 'gubica, rilo' [pysk, morda, ryj]) ${ }^{4}$. Wybrane do szczegółowszego rozpatrzenia tego typu composita były uwzględniane w przedstawieniu historii przymiotników złożonych typu białoczerwony (Ostrowska, 1948a: 6-15, 1948b: 40-47), w związku z omówieniem złożeń rzeczownikowych współczesnego języka rosyjskiego (Blicharski, 1973), struktury formalnej i struktury semantycznej przymiotników i rzeczowników złożonych w języku rosyjskim i polskim (Blicharski, 1977), złożeń rzeczownikowych w języku rosyjskim i polskim (zob. Blicharski, 1980: 81-88), udzielano im szczególniejszej uwagi w ramach badań złożeń imiennych we współczesnym języku polskim (Kurzowa, 1976), struktury i semantyki polskich i rosyjskich gniazd słowotwórczych z przymiotnikami wyjściowymi biały - бельй, сzarny - чёрный (zob. Zych, 1999: 39-86), studium semantycznego bogactwa bieli i czerni we współczesnej polszczyźnie (zob. Tokarski, 1995: 35-60).

Jak już zaznaczono wyżej, również zaprezentowane formacje kompozycyjne potwierdzają, że „referencją prototypową bieli jest śnieg” (Tokarski, 1995: 45), składnik biało wiąże się ze śniegiem, odwołując się do czegoś przypominającego go kolorem, czegoś bardzo białego, por. pol. białośnieżny, słowac. snehobiely, czes. bělosněžný, np. bělosněžné paže [ramię], białorus. беласнежны, nр. беласнежная сарочка [koszula], ros. белоснежный, белоснежность, ukr. білосніжнии, білосніжність, bułg. белоснежен, co potwierdza, że ,śnieg jako wzorzec bieli stwarza jakość najdoskonalszą, najbliższą

${ }^{2}$ Por. ros. чёрно-бельй 'przedstawiający tylko w czarnym i białym kolorze (o zdjęciu lub taśmie filmowej)'; 'niekolorowy (o fotografii, filmie itd.)'; чёрно-бельй 'kategoryczny, zbytnio wyraźny, wyrażający tylko pozytywny lub tylko negatywny stosunek do czegoś'.

${ }^{3}$ Należy zauważyć, że niektóre złożenia z biało współwystępują z obocznymi jednostkami z określeniem obiektu inną barwą, por. pol. białowłosy, siwowłosy, czarnowłosy - czes. bělovlasý, šedovlasý, černovlasý; pol. biatobrody, siwobrody, rudobrody - czes. bélovousý, šedovousý, rudovous; por. też: czes. modrovous - pol. sinobrody. W tym kontekście por. też: słowac. bielovlasý 'jasnowłosy’, np. bielovlasé dievčatko [jasnowłosa dziewczynka], bielovlasý 'siwowłosy', np. bielovlasý dedo [siwowłosy dziadek]; czes. bélovousý 'białobrody, siwobrody'.

${ }^{4}$ Ekscerpcja uwzględnia jednostki powstałe w różnym czasie rozwoju słownictwa danego języka, nastawiona jest również na odnotowanie złożeń udokumentowanych w zbiorach leksyki z końca XX i początku XXI wieku. Wykaz źródeł egzemplifikacji materiałowej zawiera bibliografia, uwzględnione zostały też jednostki znane autorowi. 
ideału: śnieżna biel jest najlepszą, najczystszą postacią białej barwy” (Tokarski, 1995: 52). Kompozycje odzwierciedlają też inne referencje bieli: z mlekiem, por. pol. białomleczny 'jak mleko biały', z marmurem, por. ros. беломраморный 'o podobnej do białego marmuru, mleczno-białej twarzy, ramionach, rękach itp.’ oraz z kością słoniową, por. głuż. běłokosć, chorw. bjelokost, bjelokostan, serb. белокост. Rozpatrywany materiał poświadcza też referencje nieprototypowe bieli, np. mąki, por. ros. бело-мучнистый (o gołębiach). Złożenia ujawniają odwołania do zjawisk błyszczenia i świecenia, por. pol. białoświetny 'biało lśniący’, białogorejacy 'płomień biały wydający’; głuż. běłožehliwy 'rozpalony (rozżarzony) do białości'; słowac. bieloskvúci 'svietiaci bielost'ou, čistotou, žiarivo biely', np. bieloskvúci hrot meča [ostrze miecza]; bieloskvúce kachličky [kafelki], bieloskvúce domčeky [domki], bieloskvúce rúcho [szata], bieloskvúce štíty Vysokých Tatier [szczyty Tatr Wysokich]; czes. běloskvoucí, np. běloskvoucí ř́za [szata], běloskvoucí kř́dla [skrzydła], běloskvoucí zuby [zęby], běloskvoucí pláně [dziczka, płonka], běloskvoucí den [dzień]; běloskvělý, np. běloskvělé ruce [ręce], běloskvělý beránek [baranek]; bělosvitný 'leskle bílý', np bělosvitné peři [pióra]; bělolesklý 'leskle bílý', np. bělolesklý šat [ubranie]; bělozářný 'bíle zařící', np. bělozářní čelo [czoło]; běložárný 'planoucí bílým žárem', np. běložárné plameny [płomienie] ${ }^{5}$.

Materiał języków słowiańskich ujawnia stosunkowo bogate słownictwo z pola barw mieszanych, por. pol. białobarwny, chorw. bjelobojan, bjelobojna, bjeloboj. Złożenia z komponentem biało i składnikiem odnoszącym do innej barwy odsyłają do różnorodnych obiektów. Odnotować można zespolenie barwy białej i żółtej, por. słowac. bieložltý 'majúci žltú farbu dobiela', np. bieložlté ovčie mlieko [owcze mleko]; bieložlté lesné plôdy [płody leśne]; bieložlté sfarbenie dobytka [zabarwienie bydła]; zelené kvety s bieložltým okrajom [zielone kwiaty z białożółtym brzegiem]; czes. běložlutý 'bílý a žlutý', np. běložlutý prapor [chorągiew, sztandar]; czes. běložlutý 'světle žlutý', np. běložluté vlásky [włosy]; czes. běložlutavý, np. běložlutavá soukenná sukně [sukienna spódnica]; ros. бело-жёлтьй. Integrowana jest barwa biała i złota, por. głuż. běłozłoty 'jasnozłoty, białozłot(aw)y'; czes. bělozlatý 'bílý a zlatý', np. bélozlatý ornát [ornat]; czes. bělozlatý 'světle zlatý', np. bělozlaté sluneční paprsky [promienie słoneczne]; ros. бело-золотистый. Biel związana jest z czerwienią, por. pol. biało-czerwony, np. biało-czerwona 'flaga, bandera polska', biało-czerwona 'sportsmenka, która reprezentuje Polskę'; ros. бело-красньй. Leksyka ujawnia melanż barwy białej i różowej, por. pol. białoróżowy, słowac. bieloružový 'majúci ružovú farbu dobiela'; czes. bělorůžový 'světle růžový', np. bělorůžové líce [lice, twarz; policzek], bělorůžový obláček [obłoczek], bělorůžová kost [kość], bělorůžový kov [metal]; czes. bělorůžový 'bílý a růžový’, np. bělorůžový květ kamélie [kwiat kamelii]. Współwystępuje biały i liliowy, por. pol. białoliliowy. Barwa biała łączy się z rudą, por. czes. bělorudý, bílorudý 'bílý a rudý', np. bělorudý praporek [proporczyk, chorągiewka]. Zespala się biały i rdzawy, por. czes. bělorezavý 'bílorezavý', np. bílorezavá skvrna [plama] 'světle rezavá'. $\mathrm{Z}$ białym zgrywana jest barwa brunatna, por. pol. białobrunatny. Biel scala się z zielenią,

${ }^{5}$ Por. też czes. bělořeřavý 'řreřavý do běla' - rozżarzony do białości, np. bělořeřavá plotna [blat kuchenny]. W odniesieniu do związku bieli z jasnością por. pol. białolicy oraz jasnolicy; czes. béloplavý 'plavý do běla', ros. бельй 'светлый, ясный', chorw. bjelojasan, bjelojasna, bjelokos - svjetlokos. 
por. czes. bělozelený 'bílý a zelený', np. bělozelený chochol [czub, kita; pióropusz]; czes. bělozelený 'zelený do běla', np. bělozelená barva moře [kolor morza]. Barwa biała wiąże się z niebieską, por. czes. bělomodravý 'modravý do běla', np. bělomodravý nádech soli [odcień soli]; czes. bělomodrý 'modrý do běla, světle modrý', np. bělomodrá mlha [mgła], bělomodré rty [wargi]; czes. bělomodrý 'bílý a modrý', np. bělomodrý chochol [czub, kita; pióropusz], bélomodré kostky [kostki; kratki]; ros. бело-голубой [błękitny]; siną, por. pol. białosiny, czes. bělosiný 'světle siný', np. bělosiná tvář [twarz]. Biel współwystępuje $\mathrm{z}$ barwą srebrną, por. czes. bělostříbrný, bělostřibrý, np. bělostříbrný opar světla [mgła światła], bělostřibrný pás potoka [pas potoku, strumienia]; ros. бело-серебристьй; szarą, por. pol. białoszary, głuż. běłošěry 'jasnoszary', czes. bělošedý 'světle šedý', bělošedý 'bílý a šedý'; szarawą, por. czes. bělošedavý, np. bělošedavá pliseň [pleśń]; siwą, por. pol. białosiwy, słowac. bielosivý 'majúci sivú farbu dobiela', czes. bělosivý 'světle sivý', np. bělosivá brada [broda]; siwą, szarą, por. czes. bělošedivý, np. bělošedivý dým [dym], bělošedivá obloha [firmament, sklepienie niebieskie], bělošedivá mlha [mgła], třtina bělošedivá [trzcina], bělošedivé proužky latky [prążki materiału, tkaniny]. Znane jest połączenie bieli i czerni, por. pol. biało-czarny, ros. бело-чёрный.

Reasumując powyższe obserwacje, należy zauważyć, że „u przeciętnego użytkownika języka różnice między ilością światła w kolorze (jasno-), intensywnością koloru (blado-) i pomniejszaniem z bielą (biało-) są często utożsamiane i realizowane wymiennie tylko z uwzględnieniem opozycji mało/dużo" (Ampel-Rudolf, 1994: 35). W odniesieniu do rozpatrywanych złożeń ma zastosowanie spostrzeżenie, że ,jednym z ważniejszych kryteriów wydzielania podstawowych nazw barw jest właściwy im zakres łączliwości - każda z nich wchodzi w związki z nazwami obiektów naturalnych" (Waszakowa, 2003: 99).

\section{Barwa biała. Struktury nieterminologiczne}

Rozpatrywany materiał poświadcza dużą liczebność kompozycji o charakterze nieterminologicznym, pozwala też wyróżnić w ich obrębie kilka zasadniczych pól tematycznych.

Zauważalne jest wyraziście odwołanie do barwy białej w obszarze odnoszącym się do człowieka.

Bogate i rozbudowane jest pole wyglądu zewnętrznego człowieka. Chodzi tu najpierw o wskazania na ludzi mających białą, jasną skórę ${ }^{6}$, białe ciało, por. pol. białoskóry, białociały, białorus. белацель, ros. белокожий, nр. белокожее тело, белотельй, czes. bělokožec, chorw. bjelokožan, bjelokožnost, bjeloputan, bjeloputna, bjeloput (bijele puti [cera], bijela tijela [ciało], bijele kože [skóra]), serb. белопym, bułg. белокож, zwłaszcza odznaczających się białym, jasnym obliczem, por. pol. białogęby, białorus. белатвары, $\mathrm{np}$. белатварая паненка [panienka], ros. белокожее лиизо, ukr. біловидий, o białych licach, posiadających białą, jasną cerę twarzy, jasnolicy, bladolicy ${ }^{7}$, por. pol. białolicy, głuż. běłoličkaty, czes. bělolíci, np. bělolící ženštiny [kobiety], słowac. bielolíci, np. bielolíca

${ }^{6}$ Także ludzi należących do białej rasy, por. pol. białoskóry; serb. белокожau; bułg. белокож 'białoskóry; człowiek rasy białej'.

7 Por. też ros. беломраморныц̆ - o mleczno-białej twarzy, ramionach, rękach itp. 
dievčina [dziewczę; pannica], bielolíce dievča [dziewczyna], białorus. белатвары, ros. белоликий, белолицый, ukr. білолиций, chorw. bjelolik, bjeloličan, bjelolikost, bjelobrazan, bjelobrazna, serb. белолик, bułg. белолик, np. белолико момиче [dziewczyna]. Utrwalona została białość czoła, por. ukr. білолобии, a także białość szyi, por. pol. białoszyi, np. szyja białosmukła ${ }^{8}$, głuż. běłošijny, serb. беловрат, беловрати. Wskazuje się na białość warg, por. ros. белогубый. Odnotowywany jest człowiek o białych zębach, mający bardzo białe zęby, por. pol. białoząb, białozęby, słowac. bielozubý, np. bielozubý spevák [śpiewak], krásna bielozubá modelka [modelka], czes. bělozubý, białorus. белазубы, ros. белозубый, np. белозубый рот [usta], белозубая ульюбка [uśmiech]', ukr. білозубий, serb. беозуб, белозуби. Rozpatrywany materiał uwidacznia białe ramiona i ręce, por. pol. białoramienny, białoręki, głuż. bèłoručkaty, słowac. bieloruký, czes. běloramenný, běloruký, np. běloruké děvče [dziewczyna], běloruké panské dítě [pańskie dziecko], ros. белорукий, ukr. білорукий, chorw. bjeloruk, serb. белорук. Uchwycona została białość kobiecych nóg, por. serb. белонога.

Charakterystyka człowieka obejmuje jasne, prawie białe włosy, brwi i rzęsy, por. stpol. białobrysy; czes. bělořasý, np. bělořasé oči [oczy]; białorus. белабрысы ${ }^{10}, \mathrm{np}$. белабрысы хлопец [chłopiec, chłopak], белабрысасцьь; ros. белобрысый, белобрысость ${ }^{11}$, np. белобрысая голова [głowa], белобрысое лищз [twarz], белобрысенький. Utrwalone zostało subtelne wyspecyfikowanie białych włosów: bardzo jasne, niemal białe kędziory, włosy jasny blond, por. pol. białokurowaty, czes. bělokadeřný, np. bělokadeřné hlavinky, białorus. белакурь, nр. белакурая дзяўчьнка, ros. белокурый, белокудрый, белокуренький ${ }^{12}$; bardzo jasne włosy, białe lub siwe włosy, por. pol. białowłosy, głuż. běłowłosaty, słowac. bielovlasý, np. bielovlasá babička [babcia], czes. bělovlasý, np. bélovlasí stařenky [staruszki], białorus. белавалосы, ros. беловолосый, nр. беловолосая голова [głowa], ukr. біловолосий, chorw. bjelovlas, bjelovlasac, bułg. беловлас, nр. беловлас cmapeu [starzec]; psł. bĕlokosъ 'wyróżniający się białymi, jasnymi włosami', chorw. bjelokos, bjelokosast, serb. белокос, белокоси, bułg. белокос, np. белокоса бабичка [staruszka, babcia], maced. белокос; białe, siwe włosy na głowie, człowiek szpakowaty, przyprószony siwizną, por. psł. bělogolvъ 'wyróżniający się białą, siwą głową, czy też jasnymi, siwymi włosami', pol. białogłowy, czes. bělohlavý, np. bělohlavý stařec, słowac. bielohlavý, np. bielohlavý starec, ros. белоголовый, białorus. белагаловы, ukr. білоголовий, chorw. bjeloglav, słoweń. beloglav, serb. белоглав, bułg. белоглав, mac. белоглав. Uwyraźnione są białe, siwe wąsy, biała, siwa broda, por. psł. běloosъ 'wyróżniający się białym, jasnym zarostem', pol. białowasy, białobrody, głuż. běłowusaty, słowac. bielofúzy, np. bielofúzy deduško [dziadek], belofúzy, bielobradý starec [starzec], czes. bělovousý, np. bělovousý stařec [starzec], bělovous, bělobradý, białorus. белавусы, белабароды, np. белабароды дзед [dziadek], ros, белобородый, ukr. біловус, білоус, біловусий, білобородий, chorw. bjelobrk, bjelobrad, serb. белобрк, белобрад, mac. белобрад, bułg. белобрад старец

\footnotetext{
8 Por. pol. białosmukty 'wysmukły i biały'.

${ }^{9}$ Por. też ros. белозубо 'pokazując, obnażając białe zęby podczas uśmiechu, śmiechu'.

${ }^{10}$ Por. białorus. белабрысы - 'płowy, jasnoblond (o włosach)', белабрысы - 'płowowłosy (o człowieku)'.

11 Белобрысый - potoczne określenie człowieka „o bardzo jasnych, płowych włosach” (Kulpina, 1998: 211).

12 Odnośnie do „poetycko czułego określenia blondyna” белокурый, zob. Kulpina, 1998: 211.
} 
[starzec]. Złożenia rejestrują bardzo jasne rzęsy, por. pol. białorzęsy; jasne, prawie białe brwi, por. pol. białobrwi, czes. bělobrvý, ros. белобровый, ukr. білобровий, chorw. bjelobrvast (bijelijeh obrva), bjelotrepast, bjelotrep, bjelotrepa, serb. белотреn.

W zebranym materiale można odnaleźć odniesienia do stanu człowieka, a konkretnie do będących w stanie białej gorączki (delirium tremens - majaczenie alkoholowe, majaczenie drżenne; szał, amok), por. ros. белогорячечник, белогорячечник, белогорячечник, a także w stanie wycofania, zamknięcia, por. chorw. kula bjelokosna - zamknięty świat, w którym chowa się ten, który unika ingerencji w sprawy publiczne i nie chce uczestniczyć w wydarzeniach ogólnych.

W obszarze odwołań do bieli w złożeniach przejrzyście zaznacza się społeczny wymiar życia człowieka.

Barwa biała wykorzystywana jest w charakterystyce aktywności, zachowania, postępowania, zwyczajach i obyczajach, stylu bycia ludzi. Uchwytne są odniesienia do cudzoziemskości, do osób z daleka, z obcych stron, por. serb. белосветски, do osób z szerokiego świata, wszędobylskich, szukających przygód, a także ze sfery półświatka, por. chorw. bjelosvjetski, np. bjelosvjetska dama [dama], serb. белосветски. Uwydatniony został stosunek do pracy fizycznej, a ściślej unikania wysiłku fizycznego, brudnej i prostej pracy, por. białorus. беларучка [paniątko, laluś], ros. белоручка, ukr. білоручка. Są złożenia odnoszące do osób mających białe konie, por. pol. białokonny. Wyjaskrawia się sposób ubierania się, ubiór w odniesieniach: do kobiety, por. pol. białogłowa 'kobieta, od białego głowy zawicia, czyli podwiki' ${ }^{13}$, chodzących w bieli, por. pol. białonoszy; ubranych w białe szaty, suknie, por. pol. białoszaty, czes. bělorouchý, np. bělorouché vily [nimfy, rusałki], bułg. белодрешковец - człowiek noszący biały strój ludowy (z północno-zachodniej Bułgarii); noszących białe koszule - o schludnie i nienagannie ubranych, por. ros. белосорочечник; noszących białe pończochy, por. chorw. bjeločarapaš; noszących białe czapki, por. serb. белокапа, белокапић ${ }^{14}$; noszących białe spodnie, por. serb. белогаћа.

Zarejestrowane są odniesienia do sfery wojskowej, por. ros. белобандит - członek kontrrewolucyjnego zbrojnego ugrupowania (w czasie wojny domowej w Rosji), ros. белоказак - Kozak, walczący w czasie wojny domowej w Rosji po stronie białych, tj. przeciw bolszewikom, czes. bělokozacký, bělokozacká vzpoura [bunt, rebelia], ros. белопогонник - pogardliwe 'służący w białej armii', ukr. білополяки, білополяк, білопольський - w określeniach wojska i żołnierzy polskich z lat 1919-1920, chorw. bjelopernik - żołnierz noszący białe pióra na znak władzy, bjeloperjanik - żołnierz z białym pióropuszem. Odnotowywane są też określenia osób niezdolnych do służby wojskowej, por. białorus. белабілетнік ${ }^{15}$, ros. белобилетник, белобилетчик.

13 Tak więc: białogłowa 'kobieta, zwłaszcza zamężna', białogłowki (zdrobnienie), białogłowski 'kobiecy, niewieści', białogłowy 'taki, który dotyczy białogłowy - kobiety, zwłaszcza zamężnej'.

14 Por. serb. белокапац - epitet stosowany w odniesieniu do Albańczyków ze względu na noszone przez nich białe nakrycie głowy.

15 Mający biały bilet, tj. zaświadczenie o zwolnieniu z obowiązkowej służby wojskowej ze względu na stan zdrowia. 
Do bieli nawiązują nazwy zwolenników opcji politycznych, por. ros. pogardliwe белоподкладочник ${ }^{16}$, określenia obrońców Białego Domu (grupy deputowanych parlamentu Federacji Rosyjskiej) we wrześniu - październiku 1993 roku przed wojskami rządowymi, por. ros. белодомовец, белодомовиьы ${ }^{17}$.

Złożenia wskazują na stosunki oraz określone procesy polityczno-społeczne, por. ros. беломестиь, беломестец ${ }^{18}$, pol. białorusinizacja 'upodobnianie się do Białorusi w jakichś dziedzinach', białorutenizacja ${ }^{19}$, białorus. беларусізаџыл, ros. белорусизащия. Mieszczą się tu nominacje reprezentantów uchodźstwa, fal emigracyjnych - osób, które wyemigrowały z Rosji w pierwszych latach porewolucyjnych, por. ros. белоэмигрант, белоэмигрантка, белоэмигрантский, ukr. білоемігрант, білоемігрантський. Odzwierciedlona jest też sfera gospodarczo-finansowa, akcentuje się w jej obszarze przedsiębiorców, urzędników, bankowców, maklerów giełdowych nastawionych na jak najszybsze osiągnięcie korzyści materialnych, a także szybkie zrobienie kariery zawodowej, por. pol. białokołnierzykowiec, a także na nielegalną działalność, pol. białoskarpetkowy, np. białoskarpetkowy biznes ${ }^{20}$.

Znane są odniesienia do barwy białej w grze w szachy, do białego pola oraz określonych figur mogących poruszać się po białych polach, por. pol. białopolowy, np. goniec białopolowy, słowac. bielopol'ný strelec, serb. белопољни ловаи/лауфер.

W obrębie budowli odnotować trzeba wskazania na: budynki z białymi murami, ścianami, por. pol. białościenny; czes. bělozděný, np. bělozděný dvior [dwór]; białorus. беласценны, nр. беласценны палац [pałac]; ros. белостенный; ukr. білостінний; ros. белодомовка (asocjacja do Białego Domu - siedziby władzy Federacji Rosyjskiej); wykonanie, wybudowanie z białego kamienia bądź białej cegły, o białych murach, por. czes. bělokámen, bělokamenný, np. bělokamenný palác [pałac], słowac. bielokamenný, białorus. белакаменны, ros. белокаменный, np. Москва белокаменная [Moskwa], ukr. білокамінний, білокам'яний, chorw. bjelokam - gypsum, bjelokamenast-gypso oppletus, serb. белокамен; budowle mające białe wieże, por. ros. белоколонный; wykonanie z białego marmuru, oblicowanie białym marmurem, por. ros. беломраморныци; wyłożenie białymi kaflami, por. ros. белокафельный; wykonane z kości słoniowej, por. chorw. bjelokostan, np. kula bjelokosna - wieża z kości słoniowej.

Do barwy białej odsyła materiał, z którego wytworzone zostały określone wyroby, do niej mają odwołania konkretne wyroby, por. głuż. běłokosćany - 'z kości słoniowej'; czes. běloplachetný 'białożaglowy', np. běloplachetná lod' [statek; łódź]; ros. беломорина -

${ }^{16}$ W Rosji przedrewolucyjnej - student z bogatej rodziny wrogo nastawiony do ruchu rewolucyjnego i tzw. demokratycznej części studentów.

17 Por. też: белодомский, белодомовский - związany z konfliktem między opozycyjnie nastawionymi deputowanymi (Rady Najwyższej Federacji Rosyjskiej), znajdującymi się w Białym Domu a władzą wykonawczą i prezydentem; znajdujący się w Białym Domu; pracujący tam; będący członkami rządu FR, mieszczącego się w Białym Domu.

${ }_{18}$ W państwie rosyjskim XVI-XVII wieku - ludność zwolniona od powinności (za zasługi dla państwa, zgodnie z przywilejami stanowymi itp.).

19 Por. w tym kontekście: białorus. беларускі, np. беларуская мова [język]; беларусазнаўства [białorusoznawstwo]; беларусіст [białorutenista]; беларусізм [białorutenizm].

${ }^{20} \mathrm{Tj}$. przedsiębiorstwo powstałe po 1990 roku z kapitału zgromadzonego niezgodnie z prawem. 
jedna sztuka papierosów „Беломорканал” (od „Беломорканал” - Białomorski Kanał), белоглавка, белоголовка, белоголовая - butelka wódki według starego wzoru, tj. zalakowana białym lakiem; chorw. bjelokorac, bjelosapac - nóż z białą rękojeścią; serb. белокор, nр. белокорац нож, јатаган, револвер [nóż, jatagan, rewolwer]; bułg. беломорски вина - egejskie wina. W sferze kucharskiej są odwołania do gotowania: białej piany podczas wrzenia, por. ros. белокипенный; produktów, potraw i napojów: oślepiającej bieli białorybicy, por. ros. белорыбий; przygotowanego z niej dania, por. ros. белорыбий бальк [bałyk (wędzony grzbiet ryb jesiotrowatych)]; regionalnej potrawy przyrządzonej z pieczonych gonad barana lub byka, por. chorw. bijeli bubrezi; rakiji ze specjalnej odmiany śliwek (bjelošlive), por chorw. bjelošlivaca; wody z gotowanych liści białej morwy, por. pol. białomorwonka.

Jednostki złożeniowe ze składnikiem biało występują licznie w rozbudowanym polu tematycznym zwierzęta. Zasadniczy blok konstytuują odwołania do wyglądu zewnętrznego zwierząt, np. maści, por. chorw. bjelomast, w tym szczególnie ptaków. Charakterystyka obejmuje: białą głowę, por. pol. białogłowy, słowac. bielohlavý, ros. белоголовый, np. белоголовая утка, белоголовый овод [giez], ukr. білоголовий, serb. белоглав, bułg. белоглав, np. белоглав кон [koń]; białe, jasne czoło, por. pol. białoczelny, słowac. bieločelý, ros. белолобый; bardzo jasne, niemal białe oczy, por. pol. białooki, ros. белоглазый, белоглазка, ukr. білозорий, chorw. bjelook, bjelookast, serb. белоок, белоокаст, белоока; białe uszy, por. chorw. bjelouhast; serb. белоушка (о оwсу); białą, jasną, siwą grzywę, zwłaszcza konia, por. pol. białogrzywy, np. białogrzywe konie, czes. bělohřívý, np. bělohř́vý kůn̆ [koń], ros. белогривый, białorus. белагрывы, пр. белагрывыя коні [konie], ukr. білогривий, chorw. bjelògriv, słowac. bielohrivý, np. bielohrivý kôň [koń], serb. беогрив, белогрив; białą mordę, por. czes. bělohubý, ros. беломордый; biały dziób, por. czes. bělozobý, np. bělozobý stehlík [szczygieł]; białe kły, por. pol. białokływy; białe pióra, białą sierść lub białą plamkę na policzkach, por. ros. белощёкий, np. белощчекий сапсан [Falco peregrinus, sokół wędrowny], белощекая крачка [Sterna, rybitwa]. W rozpatrywanych złożeniach wyraźnie zaznaczona jest: biała szyja, por. pol. białoszyjka 'zwierzę, które cechuje się białą szyją, koń, klacz, krowa’; białe gardło, por. pol. białogardt, chorw. bjelogrli, bjelogrlast, serb. беогрл, белогрли, беогрласт; biały kark, por. czes. bělokrký, np. bělokrká koza [koza]. Z innych części ciała zwierząt odnotować można: biały grzbiet, por. pol. białogrzbiety, bydło białogrzbiete, czes. bělohřbetý, np. bělohřbetý dobytek [bydło, zwierzęta domowe]; biały brzuch, białe pióra lub sierść na brzuchu, por. pol. białobrzuszek, ros. белобрюхий; biały bok, białe, jasne boki, por. ros. белобокий, białorus. белабокi, nр. белабокая сарока [sroka]; białą pierś, białe pióra, białą sierść lub białą plamkę na piersi, por. ros. белогрудый, nр. белогрудый медведь [niedźwiedź]; białorus. белагруды, np. белагрудыя ластаўкі [jaskółki]; ukr. білогрудий; chorw. bjelogrud. Kolejną grupę tworzą wskazania na: białe skrzydła, por. pol. białoskrzydty, głuż. běłokřidtaty, słowac. bielokrídly vták [ptak], czes. bělokřidlý, np. bělokřídlý pták [ptak]; běloperutný, np. běloperutná havět' [drób, ptactwo] (o mewach); białorus. белакрьльь, ros. белокрыльй, ukr. білокрилий, chorw. bjelokril, np. bjelokrili galeb [mewa], serb. белокрил, белокрили, bułg. белокрил; białą rękę, por. słowac. bieloruký, np. bieloruký gibon [gibon]; białe, jasne nogi, por. psł. bĕlonogъ 'wyróżniający się białymi nogami', 
pol. białonogi, np. białonogie zwierzę, białonogi końn ${ }^{21}$, głuż. bĕlonohi, bělknohaty, czes. bĕlonohý, słowac. bielonohý, belonohý, ros. белоногий, ukr. білоногий, białorus. беланогi, chorw. bjelonog, chorw. bjelonog, słoweń. belonog, serb. белоног, bułg. белоног, mac. белоног; białe kopyta lub nogi poniżej kolan, por. ukr. білокопитий; biały ogon, por. psł. bĕloritъ 'ptak wyróżniający się białym, jasnym ogonem', pol. białogony, białoogonny, ros. белохвостый, chorw. bjelorepi, serb. белореп.

Do bieli odsyła wyraźnie uwłosienie, upierzenie oraz inne pokrycie powierzchni ciała zwierząt. Chodzi w szczególności o: białą lub bardzo jasną sierść, por. czes. bělosrstý, np. bělosrstá lan̆ [łania], ros. белошёрстый, белошёрстный; białe runo (wełnę), por. czes. bělorouný, np. bělorouné ovce [owca], chorw. bjelorunost, bjelorun, np. bjeloruna ovca [owca], serb. белорун, ros. белорунный; białe pióra w kolorze śniegu, białe upierzenie, por. pol. białopióry, np. białopióry ptak, głuż. běłopjeraty, czes. běloperý, np. běloperé labutě [łabędzie], ros. белопёрый, ukr. білоперий, chorw. bjeloperan, bjeloperna, serb. белопер $($ ан); biały puch, por. pol. białopuchy; białe łuski, skorupę, por. chorw. bjeloljusak, bjeloljuska, bjeloljuskav.

W budowie złożeń, które mogą być uznane za nieterminologiczne, zauważalnie wykorzystywana jest barwa biała w sferze roślinnej. Utrwalona została biel, białość kwitnących drzew, krzewów, kwiatów, por. głuż. běłokćějny, ukr. білоиявіт, білоиввіття; białość podobna do białej piany, zwykle obficie kwitnących drzew i krzewów, por. ros. белопенныци; miejsce, w którym ziemia pokryta jest białym mchem, por. ros. беломошньй; drzew liściastych, por. chorw. bjelogorično drvo [drzewo liściaste], bjelogorica, bjelogoričan, bjelogoroični, serb. белогорица, белогорични; białość wielu pni brzozy, por. ros. белостволье; chorw. bjelojabuka [gatunek jabłoni, jabłek w dzielnicy Šumadija]. Z innych nazw przywołać można: rosnący na glebie pokrytej jasnym mchem bór sosnowy, por. ros. беломошник; biały pień drzew, por. pol. białopienny, czes. bělokmenný, bélokmenná bríza [brzoza], ros. белоствольный, białorus. беластволь, nр. беластволья бярозы [brzozy]; jasną, białą korę, por. pol. białokory, słowac. bielokôrový, np. bielokôrova lipa [lipa], czes. bélokorý, bélokorá břiza [brzoza], ros. белокорый, ukr. білокорий, chorw. bjelokoran, serb. белокор, bułg. белокор, белокож, белокоралипа; białe pędy, por. pol. białopędny, chorw. bjeloloza (bijela loza [winoroś1]), bjeloružina, bjelolijeska [winorośl białych winogron uprawianych w Dalmacji]; białe liście, por. pol. białolistny, czes. bělolistý, serb. белолист, białorus. белалісты; białe kwiaty, por. czes. bélokvětý, np. bělokvětýjasmín [jaśmin], šafrán bělokvětý [szfran], serb. белоияетни, bułg. белоиветен; białoskóre owoce: serb. белокорка 'бундева [dynia]'; białe nasiona, białe ziarno, por. czes. bělosemenný, np. bělosemenný mák [mak], głuż. běłozornity, ukr. білозерний, np. білозерна пшениия [pszenica]; białe kłosy, por. czes. běloklasý, por. běloklasá vouska [wąsatka (pszenica)]; biały głąb, por. białorus. белакачанны, np. белакачанная капуста [kapusta], ros. белокочанный, np. белокочанная капуста [kapusta]; biały miąższ, por. czes. bělomasý, np. bělomasé brambore [ziemiaki].

${ }^{21}$ Por. też nazwy białego konia, por. pol. białosz, serb. белащ; konia lub klaczy o białych, jasnych nogach, por. pol. białonóżka, głuż. np. béłonohač. 
Barwa biała utrwalona została w odniesieniach do nieba, ściślej - do białych chmurek, którymi przesłonięte jest niebo, por. chorw. bjelovedrina, wiązana jest ona $\mathrm{z}$ wodą w odniesieniu do spienionego wierzchołka (grzebienia) fali zaginającego się w kierunku wiatru, por. ros. белогривый oraz bardzo obficie spienionej białą pianą fali, por. pol. białopienny, czes. bělopěnný, np. bělopěnné proudy, ros. белопенный. Barwa biała ujawnia się w określeniach opadów i zjawisk atmosferycznych: opadu śniegu, por. pol. białonapadty; deszczu ze śniegiem, por. chorw. bjelokapac; czegoś pokrytego białym śniegiem, por. ros. белоснежный; zaśnieżonej przestrzeni, por. ros. белоснежье; pory i zjawiska białych nосу, por. ros. белоночье; wiatru południowego bez deszczu, por. chorw. bjelojug, bjelojugovina, bjelojužina; wiatru południowego od Morza Egejskiego, por. bułg. беломореu; odzwierciedla się w nazwach określonego rodzaju ziemi, gleby, por. bułg. белозем oraz kruszcu koloru podobnego do ołowiu, por. pol. białokrusz.

Białość odnoszona jest do istot nieba - aniołów z białymi skrzydłami, por. czes. bělokř́llý anděl. Złożenia z komponentem biało widoczne są w sferze religijnej w odniesieniu do Wielkiej Soboty, por. czes. bělosobotni 'bílosobotní, rel. Bílá Sobota', np. bělosobotni zvonění [dzwonienie, dzwony], bělosobotní vajička [jajka, jajeczka].

W analizowanym materiale są złożenia, w których precyzowane jest występowanie białych elementów na jakimś tle, w jakimś ułożeniu, mianowicie: pstrość, barwność, por. pol. białopstry, głuż. běłokrjepjeny, czes. bělopruhý, np. bělopruzí holubi [gołębie], běloplstnatý; chorw. bjelošaran, bjelošarna, bjeloštrampan; pstrokatość, srokatość, por. czes. bělostrakatý, np. bělostrakatý kůn̆ [koń]; pręgowatość, por. pol. biało-pregowany.

Odrębnego przedstawienia wymagają wysublimowane złożenia z komponentem biało kwalifikowane jako podniosłe, książkowe, często jako stałe epitety, pojawiające się zwłaszcza w poezji i w folklorze, por. pol. białowonny 'biały, a przy tym przyjemnie pachnący, np. kwiat'; czes. bělotřpytný 'bíle se třpytíci', np. bělotřpytná tunika [tunika], bělotřpytná hvězda [gwiazda]; ros. белоярый ‘белояровый’, белояровый ‘в сказках, былинах и т. п. яровой, лучший из его сортов (о пшенице, просе и т. п.)’, пр. белояровая пшенииа [pszenica], белояровое пшено [jagły, kasza jaglana]; белоствольная берёза [brzoza]; ukr. білозір 'постійний епітет назв білозорих, яснооких людей, тварин, птахів, а також місяця'; chorw. bjelodan 'koji ne ostavlja mjesta sumnji, jasan, očigledan', np. bjelodan dokaz [dowód], bjeločano 'javno, očito'; serb. беодан; тас. белоденски; bułg. белоствол, np. белоствола бреза [brzoza]; белокрили чайки [mewy].

\section{Barwa biała. Struktury terminologiczne. Nazwy oficjalne}

Bogaty jest zasób terminologiczny złożeń z komponentem biały, który stanowią głównie terminy biologiczne, anatomiczno-medyczne i techniczne.

Reprezentatywny zbiór terminów botanicznych obejmuje przede wszystkim byliny (rośliny zielne), w szczególności z odwołaniem do bieli kwiatów i liści: słowac. bielokvet, por. bielokvet močiarny, Parnassio palustris, dziewięciornik błotny; bielokvetovité, Parnassiaceae, dziewięciornikowate; bieloprst, por. bieloprst belavý, Pseudorchis albida, gołek białawy; bielokvetý, tradeskancia bielokvetá, Tradescantia albiflora, trzykrotka 
wężykowata, šafran bielokvetý, Crocus albiflorus, szafran wiosenny; bielolist, por. bielolist pol’ný, Filago arvensis, nicennica polna; czes. bělolistý, por. dřištál bělolistý, Berberis candidula, berberys sinawy; bělotrn, Echinops, przegorzan; bělozárka, Anthericum, pajęcznica, np. bělozárka liliovitá, bělozárka větvovitá; białorus. белакапьтнік, Petasites, lepiężnik; белакудранік, Ballota nigra, mierznica czarna; ros. белокопытник, Petasites, lepiężnik; белоус, Nardus, bliźniaczka; белокрыльник, Calla, czermień; белозор, Parnassia, dziewięciornik; ukr. білозір, por. білозір болотяний, Parnassia palustris, dziewięciornik błotny; chorw. bjeloglavica, Dorycnium germanicum, szyplin jedwabisty; bjelolist, Filago germanica, Filago arvensis, nicennica polna; bjeloglavica, bjeloglavka, Dorycnium tourn, komonica; bjelonoga, Saponaria, mydlnica; bjeloperka, Verbascum thapsus, dziewanna drobnokwiatowa; bjelozrnac, Lithospermum officinale, nawrot lekarski; bjelozrno, Lithospermum purpureo-coeruleum, nawrot czerwonobłękitny; bjelotrn, Echinops, przegorzan; bjelotrava, Convallaria polygonatum, kokoryczka wonna; bjelokopitnak, Tussilago farfara, podbiał pospolity; bjelodulija, Hyacinthus orientalis, hiacynt wschodni; bjelobrada, Helichrysum stoechas, kocanka (nieśmiertelnik); bjelobrada, Helichrysum angustifolium, kocanka włoska; serb. белонога, Saponaria, mydlnica; беодун, белодун, Anthyllis vulneraria, przelot pospolity.

Wśród terminów botanicznych są też nazwy drzew: pol. białodrzew, Populus alba, topola biała; białodrzewo; ros. белолистка, ukr. білолистка; chorw. bjelošljiva, bjelopandara, białucha, śliwa lubaszka; bjelograb, Carpinus betulus, grab; bjelobor, Pinus sylvestris, sosna pospolita; chorw, bjelolipa, Tilia tomentosa, lipa srebrzysta; serb. белошљива, Prunus institia, śliwa lubaszka; београб, grab; белолипа, Tilia tomentosa, lipa srebrzysta, белобор, sosna pospolita; mchów: słowac. bielomach, por. bielomach sivý, Leucobryum glaucum, bielistka siwa; czes. bělomech, np. bělomech sívy; grzybów: słowac. bielohl'uzovka, por. bielohluzovka obyčajná, Cholromyces venosus, piestrak jadalny. Spotykane są odniesienia do białego koloru warzyw, por. chorw. bjelorepast (bijela repa - biała rzepa).

Kolejną grupę formułują terminy zoologiczne. Bogato reprezentowane są terminy ornitologiczne, por. stpol. białorzyt, Strigiceps cineraceus; białorzytka zwyczajna, Oenanthe oenanthe; pol. białoczółka, gęś białoczelna, Anser albifrons; białogon, Haliaeetus albicilla, bielik; białogon, Saxicola oenanthe, opocznik; białosep, Nephron peneropterus; białozór, Falco rusticolus; białoszpon; pliszka białogardła; głuż. béłozor, Falco articus; běłoražk, biegus, brodziec; dłuż. běoritk, Oenanthe oenanthe; słowac. beloritka, Delichon urbica, oknówka zwyczajna; sup bielohlavý, Gyps fulvus, sęp płowy; muchárik bielokrký, Muscicapa albicollis, muchołówka białoszyja; datel bělohřbetý; hus bieločelá; strnádka bielohlavá, Emberiza leucocephala, trznadel białogłowy; strnádka rolná, Emberiza rustica, trznadel czubaty; stczes. bĕlořit, Calidris, bekasowate; bĕlořitka, Oenanthe oenanthe; czes. bělořit, Oenanthe oenanthe; bělozor; sup bělohlavý; ros. белоглазка; chorw. bjelozor, Falco rusticolus, białozór; bjeloglavi sup; bjelogrli sup, Nephron perenopterus, białosęp; bjelorepka; bjelorepi štekavac; bjelonokta vjetrusa, Falco naumanni, pustułeczka, białoszpon; bjelovrati kos, białobrąż, drozd obrożny; lasta bjelogrla, jaskółka oknówka; modrovoljka bjelogrla, bjelokrpica, gajówka modra; chorw. muharica bjelokrilica, bjelovrata, Ficedula albicollis, muchołówka białoszyja; bjelobrada čigra, Chlidonias hybrida, rybitwa białowąsa; bjelokrila čigra, Chlidonias leucopterus, rybitwa 
białoskrzydła; bjeloglava patka, Oxyura leucocephala, sterniczka, sterniczka białogłowa; bjelokrila ševa, Alauda arvensis, kalandra białoskrzydła, skowronek białoskrzydły; bjelolika guska, Branta leucopsis, bernikla białolica; bjelouška, Notiomystis cincta, miodnik, białouszka; bjelobrada burnica, Procellaria aequinoctialis, burzyk białobrody; serb. белорепа; beloglavi kraguj; белоглави cyn, Gyps fulvus, sęp płowy; белоглави орао, Haliaeetus leucocephalus, bielik amerykański; беловрана, Corvus cornix, wrona siwa; беловрати гавран, Corvus albicollis, kruk wielkodzioby; белоглава патка, Охуига leисосерhala, sterniczka, sterniczka białogłowa; белокрила шева, Alauda arvensis, kalandra białoskrzydła, skowronek białoskrzydły; белогрли славуj, Irania gutturalis, iranka; ветрушка белонокта, Falco nаuтаппі; беловрати врабаu, Zonotrichia albicollis, pasówka białogardła; słoweń. dial. beloritka, Oenanthe oenanthe; beloritec, por. lunj beloritec, Circeus pygargus, błotniak łąkowy, błotniak popielaty; bułg. белоглав орел; белоглав лешояд; белоопашат мишелов; беловрата мухоловка; белоглава овесарка, Emberiza leисосерhala; bułg. белогуша овесарка, Emberiza rustica.

W rozpatrywanym materiale odnaleźć można nazwy ssaków: słowac. bielozúbka, por. bielozúbka najmenšia, Suncusetruscus, ryjówek etruski; czes. bělozubka, ukr. білозубка, Crocidura, zębiełek; ros. белодушка (каменная куница), Martes foina, kuna domowa, kuna kamienna; ros. белобочка, Delphinus delphis, delfin zwyczajny; ukr. білобочка; chorw. bjeloglavi nakari, Cacajo/Uacarta alvux; chorw. bjelorepi jelen, Odocoileus virginianus, mulak białoogonowy; kandžaš bjelouhi, krętogon; majmun bjelouhi, krętogon, skomlik; bjeloruki gibon, rodzina Hylobatidae, gibon białoręki; serb. белорепи гну, Connochaetes gnou, gnu brunatne. Biel akcentowana jest w nazwach płazów i gadów: chorw. bjelouška, Natrix natrix, zaskroniec zwyczajny; serb. белоушка, Tropidonotus natrix, wąż z rodziny połozowatych. Badany materiał odzwierciedla nazwy owadów: słowac. bielopásovec, bielopásovec topolový, Limenitis papuli, pokłonnik osinowiec; bielopásovec zemolezový, Limenitis camilla, pokłonnik kamilla; trúdovka bielofúza, Eristalis arbustorum, gnojka bajorowa; czes. bělopásek, Limenitis, np. bělopásek zimolezový; chorw. bjelonog, np. gnojolub bjelonogi, Philonthus albipes, nawozak. Odnotowywane są nazwy ryb: pol. białorybica, Stenodus leucichthys; białorus. беларыбіиа, Stenodus leucichthys, białorybica; ros. белорыбица, Stenodus leucichthys, białorybica; ukr. білорибиия; білоочка, chorw. bjeloperka, Leuciseus rutilus, płoć; serb. белоперка, bułg. белоперка; serb. белорибе - ogólna nazwa większości ryb z rodziny karpiowatych.

Kolejną kategorię wyznaczają złożenia będące terminami medycznymi i anatomicznymi, w szczególności nazwami chorób: por. pol. białopłynnie - upław biały kobiecy; czes. bělotok - upławy; chorw. bjeloočnica - twardówka, białkówka; bjelokožnica, bjelopjegavost - bielactwo, bezbarwność skóry; bjelopjegava koža - bialica; bjelopjegavost usmena - łuszczyca jamy ustnej, bjelopjegav - pokryty białymi plamami, znamionami; bjelozrnik - guz limfatyczny; mac. белодробен - płucny; bułg. белодробен - płucny; белодробни болести - choroby płuc; белодробна туберкулоза - tuberkuloza; белодробна емфизема - rozedma płuc. Wyraźnie zaznacza się terminologia związana z krwinkami białymi, komórkami krwi i limfy: pol. białokrwinkowy, por. układ białokrwinkowy, ukr. білокрівиіi; słowac. bielokrvnost'- białaczka, czes. bělokrevnost, chorw. bjelokrvnost, serb. белокрвност, białorus. белакроўе, ros. белокровие, ukr. білокрів'я. 
Terminy techniczne reprezentowane są przez nazwy rzemiosł (zawodów) i wykonawców zawodów, por. pol. białoskórnictwo 'dział garbarstwa, rzemiosło lub przemysł, który zajmuje się wyprawianiem miękkich skór na rękawiczki i odzież', białoskórniczy 'taki, który dotyczy białoskórnictwa', por. garbarnia białoskórnicza, rzemiosło białoskórnicze, przemysł białoskórniczy, białoskórnik 'garbarz, co białe skóry wyrabia', 'garbarz, który zajmuje się wyprawianiem miękkich skór na rękawiczki i odzież', białoskorniczyk 'czeladnik białoskórniczy'; białorus. белашвейнь 'związany z szyciem bielizny, bieliźniarski', por. белашвейнае атэлье [pracownia bieliźniarska]; белашвачка 'kobieta, która szyje bieliznę', 'bieliźniarka (szwaczka)', ros. белошвейный 'związany z szyciem bielizny (przeważnie delikatnej)', белошвейка 'kobieta, która zajmuje się szyciem bielizny (przeważnie delikatnej)'; białorus. беладрэуишчыл, ros. белодеревец, белодеревщик 'stolarz, wytwarzający proste, niepolerowane wyroby', 'stolarz, wytwarzający meble z białych gatunków drzewa, bez sklejkowego wykończenia'.

Ze sfery społecznej życia człowieka wymienić można oficjalne nazwy odnoszące się do konkretnych formacji i ugrupowań wojskowych, por. pol. białogwardzista, białogwardyjski, np. białogwardyjska konnica, białogwardyjscy żołnierze; słowac. bielogvardejec, bielogvardejský; czes. bělogvardějec, bělogvardějský; białorus. белагвардзееu; ros. белогвардееи, белогвардейский; ukr. білогвардієць, білогвардійський, білогвардійщчина; chorw. bjelogardijac; bułg. белогвардееu, белогвардейски. Złożenia wskazują na przynależność herbową, por. pol. Białokurowicz.

Złożenia z komponentem biały dokumentują niektóre onimy. Są wśród nich: nazwy państw, por. Беларусь [Białoruś]; chorw. Obala Bjelokosti (Bjelokosna Obala) [Wybrzeże Kości Słoniowej]; nazwy narodowości, plemion, por. białorus. беларусы [Białorusini]; chorw. Bjelopavlići - plemię w Czarnogórze; nazwy miejscowe ${ }^{22}$, por. pol. Białogród; chorw. Bjelovar - miasto u podnóża Bilogore, Bjelograd; serb. Beograd; nazwy mieszkańców, por. chorw. Bjelopoljac - człowiek z Białego Pola; bułg. беломорец [Egejczyk (mieszkaniec wybrzeża Morza Egejskiego)], беломорка [Egejka]; nazwy wodne, por. ros. Беломорканал [Białomorski Kanał] 23; imiona, por. chorw. Bjeloslav - imię męskie.

\section{Podsumowanie}

Zbiór rozpatrzonego materiału języków słowiańskich (konstrukcji regularnych typu białoczerwony oraz innych typów kompozycyjnych) jest bogaty. Pod względem chronologicznym obejmuje liczne złożenia utrwalone w języku od dawna oraz dość liczebne jednostki nowsze lub nowe, w szczególności powstałe w trzech ostatnich dziesięcioleciach, co świadczy o żywotności tego sposobu słowotwórczego ${ }^{24}$.

${ }^{22}$ Poprzez odwołania do nazw miejscowych wskazywane są miejsca bitew, określone wydarzenia itp., por. czes. bělohorský [od Bílá hora - Biała Góra], np. bělohorská bitva [bitwa], pobělohorský doba [okres, epoka (po bitwie)].

${ }_{23}$ Por. w tym kontekście pol. białomorski, ros. беломорный, czes. bělomorský, od Morze Białe.

${ }^{24}$ Istotnie rola tworzenia złożeń jest obecnie wciąż znacząca, mianowicie ,po roku 1989 można zaobserwować przyśpieszone zmiany w słowotwórstwie języka polskiego, a także innych języków słowiańskich”, przy czym chodzi tu przede wszystkim o ekspansję struktur złożeniowych, tj. niemających typowych wykładników morfologicznych (słowotwórczych), złożeń bezafiksalnych, które można „traktować oddzielnie od «tradycyjnych» złożeń na gruncie słowiańskim" (Rudnik-Karwatowa, 2007: 157). 
W zasobach leksykalnych wyraźnie zauważalne są odwołania do różnorodnych obiektów o barwie białej. Spektrum wyznaczane przez analizowane złożenia obejmuje kilka zasadniczych wycinków rzeczywistości, w szczególności uchwytne są odniesienia do człowieka w wymiarze indywidualno-jednostkowym oraz życia społecznego, zwierząt oraz roślin, w mniejszym stopniu do innych elementów świata. Niektóre człony złożenia występują w jednostkach mających więcej niż jedno odniesienie z różnymi znaczeniami ${ }^{25}$. Wiele złożeń ma swoje odpowiedniki w kilku lub we wszystkich analizowanych językach słowiańskich, oczywiście są też specyficznojęzykowe połączenia z biało. Wiele złożeń występuje w roli komponentu połączeń wielowyrazowych.

Dokonane dociekania umiejscawiają rozpatrywane jednostki złożeniowe z komponentem kolorystycznym biało w polu możliwości derywacyjnych, naświetlają ich specyfikę pod względem łączliwości tego składnika, a tym samym osadzają rezultaty dociekań w szerszej płaszczyźnie poszukiwań odniesień obiektowych barwy białej w konfrontacji międzyjęzykowej (por. Wysoczański, 2014: 567-585), a także w sferze odniesień podstawowych nazw barw, żeby ,pokazać, do jakich klas nazw obiektów i zjawisk naturalnych bywa odnoszona dana nazwa w określonym języku” (Waszakowa, 2000: 61).

\section{Bibliografia}

\section{Źródła}

Anić V. (1991), Rječnik hrvatskoga jezika, Zagreb.

Anić V., Matasović R., Pranjković I., Brozović Rončević D., Goldstein I., Goldstein S., Jojić L., Cikota L. (2003), Hrvatski enciklopedijski rječnik, Zagreb.

Bělič J. (1989), Slovník spisovného jazyka českého, t. 1, Praha.

Brodnjak V. (1998), Razlikovni rječnik srpskog i hrvatskog jezika, Zagreb.

Buceva T.N. (red.) (2009), Novye slova i značeniâ. Slovar'-spravočnik po materialam pressy i literatury 90-h godov XX veka, t. 1, Sankt-Peterburg.

Busel V.T. (red.) (2003), Velikij tlumačnij slovnik sučasnoï ukraïns'koïmovi, Kiïv.

Buzássyová K., Jarošová A. (red.) (2006), Slovník súčasného slovenského jazyka, t. I-II, Bratislava.

Chylak-Schroeder T., Głuszkowska-Babicka J., Jasińska-Socha T. (red.) (2012), Słownik białorusko-polski, Warszawa.

Daničić Đ. (1880-1882), Rjecnik hrvatskoga ili srpskoga jezika, t. I, Zagreb.

Denisenko Û.F. (red.) (2005), Novoe v russkoj leksike. Slovarnye materialy - 1991, Sankt-Peterburg.

Denisenko Û.F. (red.) (2006), Novoe v russkoj leksike. Slovarnye materialy - 1994, Moskva.

Dunaj B. (1996), Słownik współczesnego języka polskiego, Warszawa.

Frančić V. (1987), Słownik serbsko-chorwacko-polski, t. I-II, Warszawa.

\footnotetext{
${ }_{25}$ Por. np. pol. białogłowy, ros. белоголовый - o człowieku oraz o zwierzęciu.
} 
Gorbačevič K.S. (red.) (2004), Bol'šoj akademičeskij slovar' russkogo âzyka, t. 1, Moskva Sankt-Peterburg.

Košková M. (2013), Bulharsko-slovenský slovník, t. II, Bratislava.

Košková M., Dobríková M., Ďulgerova G., Nikolova N. (2004), Bulharsko-slovenský slovník, t. I, Bratislava.

Kotelova N.Z. (red.) (1984), Novoe v russkoj leksike. Slovarnye materialy - 80, Moskva.

Kotelova N.Z. (red.) (1986), Novoe v russkoj leksike. Slovarnye materialy - 81, Moskva.

Kotelova N.Z. (red.) (1986), Novoe v russkoj leksike. Slovarnye materialy - 82, Moskva.

Kotelova N.Z. (red.) (1989), Novoe v russkoj leksike. Slovarnye materialy - 84, Moskva.

Kotelova N.Z. (red.) (1995), Slovar' novyh slov russkogo âzyka (seredina 50-h - seredina 80-h godov), Sankt-Peterburg.

Linde S.B. (1807), Słownik języka polskiego, t. I, cz. 1, Warszawa.

Moguš M., Pintarić N. (2002), Poljsko-hrvatski rječnik, Zagreb.

Moskovlević M.S. (2000), Rečnik savremenog srpskog kn̂iževnog jezika s jezičkim savetnikom, Belgrad.

Pianka W., Topolińska Z., Vidoeski B. (1990), Słownik macedońsko-polski i polsko-macedoński, Warszawa.

Sklârevskaâ G.N. (1998), Tolkovyj slovar' russkogo âzyka konca XX veka. Âzykovye izmeneniâ, Sankt-Peterburg.

Sławski F. (red.) (1974), Stownik prasłowiański, t. I, Wrocław-Warszawa-Kraków-Gdańsk.

Smółkowa T. (2010), Nowe słownictwo polskie. Materiały z prasy lat 2001-2005, cz. I: A-D, Kraków.

Smółkowa T. (red.) (2004), Nowe słownictwo polskie. Materiały z prasy lat 1993-2000, cz. I, Kraków.

Sudnik M.R., Kryuko M.N. (2005), Tlumačal'ny slounik belaruskaj litaraturnaj movy, Minsk. Zeman H. (1967), Słownik górnołużycko-polski, Warszawa.

Zgółkowa H. (1995), Praktyczny słownik współczesnej polszczyzny, t. IV, Poznań.

Živanović Đ. (red.) (1999), Polsko-srpskirečnik u dva toma, t. 1-2, Beograd.

\section{Literatura}

Ampel-Rudolf M. (1994), Kolory. Z badań leksykalnych i składniowo-semantycznych języka polskiego, Rzeszów.

Blicharski M. (1973), Złożenia rzeczownikowe współczesnego języka rosyjskiego, Opole.

Blicharski M. (1977), Złożenia imienne w języku rosyjskim i polskim. Studium kontrastywne, Warszawa-Wrocław.

Blicharski M. (1980), Struktura semantyczna rzeczowników złożonych z odrzeczownikowym tematem $w$ drugim członie w języku rosyjskim i polskim, [w:] M. Blicharski (red.), Semantyka w badaniach konfrontatywnych języka rosyjskiego i polskiego, Katowice. 
Budniak D. (1987), Studium konfrontatywne łączliwości leksykalnej rosyjskich i polskich leksemów oznaczających kolor, Opole.

Grzegorczykowa R. (1984), Zarys słowotwórstwa polskiego. Słowotwórstwo opisowe, Warszawa.

Ignatowicz-Skowrońska J. (2010), Wyrażenie „,biały kruk” w dziejach języka polskiego, „Studia Językoznawcze”, t. 9.

Kulpina W. (1998), Określenia koloru włosów w języku polskim i rosyjskim, „Studia Rossica”, t. VI.

Kurzowa Z. (1976), Złożenia imienne we współczesnym języku polskim, Warszawa-Kraków.

Ostrowska E. (1948a), Z historii przymiotników złożonych typu „, biało-czerwony” $i$,jasnoniebieski”, „Język Polski”, nr XXVIII, z. 1.

Ostrowska E. (1948b), Z historii przymiotników złożonych typu „,biało-czerwony” $i$,jasnoniebieski”, ,Język Polski”, nr XXVIII, z. 2.

Osuchowska D. (2010), Łączliwość leksykalna przymiotnika biały w ujęciu diachronicznym, „Podkarpackie Forum Filologiczne. Seria Językoznawstwo”.

Rudnik-Karwatowa Z. (2007), Ekspansja struktur złożeniowych w językach słowiańskich. Diagnoza i rokowania, „Biuletyn Polskiego Towarzystwa Językoznawczego”, LXIII.

Skorupska-Raczyńska E. (2003), Frazeologizmy z komponentem czarny, biały, szary w polszczyźnie historycznej, „Studia Językoznawcze”, t. 2, Synchroniczne i diachroniczne aspekty badań polszczyzny.

Tokarski R. (1995), Semantyka barw we współczesnej polszczyźnie, Lublin.

Waszakowa K. (2000), Struktura znaczeniowa podstawowych nazw barw. Założenia opisu porównawczego, [w:] R. Grzegorczykowa, K. Waszakowa (red.), Studia z semantyki porównawczej. Nazwy barw. Nazwy wymiarów. Predykaty mentalne, cz. 1, Warszawa.

Waszakowa K. (2003), Językowe i kulturowe odniesienia nazwy barwy żółtej we współczesnej polszczyźnie, [w:] R. Grzegorczykowa, K. Waszakowa (red.), Studia z semantyki porównawczej. Nazwy barw. Nazwy wymiarów. Predykaty mentalne, cz. 2, Warszawa.

Wysoczański W. (2014), Nowe (na tle dawniejszych) zestawienia i niektóre połaczenia wyrazowe z komponentem-nazwa barwy białej, [w:] D. Dziadosz, A. Krzanowska, A. Szlachta (red.), Stałość i zmienność w językach i kulturach świata, t. I, Szczecin.

Zaręba A. (1954), Nazwy barw w dialektach i historii języka polskiego, Wrocław.

Zych A. (1999), Struktura i semantyka polskich i rosyjskich gniazd stowotwórczych z przymiotnikami wyjściowymi nazywającymi barwę, Katowice. 


\section{Abstract \\ Compound units with the lexical component 'white' ('biało') in Slavic languages}

Among compound units with the name of white (biało) in linguistic resources compound units, in particular, clearly constitute a group. The material of Slavic languages under consideration confirms a large number of compound units with reference to the white color of non-terminological character. Within them one can distinguish several basic thematic fields, the most representative of which are referring to a human being, first of all to the external appearance and social dimension of life, as well as animals located in the subject area. The terminological resource of compounds with the "white" component is also rich, which are mainly biological terms - botanical and zoological, anatomical-medical and technical, to a lesser extent belonging to other elements of the world.

Keywords: white color (biały); color analysis; compound units; Slavic languages 